\title{
Thermal Analisys of the Increase in Ambient Temperature Due to Motor Vehicle Activities
}

\author{
Mohammad Imran, Sangkertadi, Cynthia E. V. Wuisang, Abdul Rahmat
}

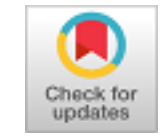

\begin{abstract}
Global warming has become a problem of world wide, because it endangers living things. The consequences of global warming include the increase of the earth temperature and climate change. The increase of temperature (heating) in a city which is referred to urban heat island (UHI) is also the same problem in architecture. This research aimed to analyze the ambienttemperature of the UHI due to the motor vehicleactivities. Samples were taken from several locations: (1) Bahu Mall Parking area; (2) Manado Town Square 2 parking area; (3) along the Wolter Monginsidi street in front of Bahu Mall and (4) along the Piere Tendean street in front of Manado Town Square. This research used a quantitative method with a field survey. This research found that the ambient temperature increased when motor vehicles were stationary with engine on or moved. The temperature increased due to the heat from the engine and the reflection of the sun's heat from the body of the vehicles. The heat level obtained from the survey was $34,8{ }^{\circ} \mathrm{C}$ to $39,4{ }^{\circ} \mathrm{C}$. For this reason, a specific material for vehicle's body is needed to prevent the increase of ambient temperature.
\end{abstract}

Keywords: urban heat island, thermal analisys, motor vehicle activities

\section{INTRODUCTION}

Global warming is a form of ecosystem imbalance on earth caused by an increase in ambient temperature (thermal). Global warming has become an issue and an international problem because it can endanger living things, the consequences of this global warming include increasing the temperature of the earth and the occurrence of climate change (climate change). Various kinds of concern from the international community towards cases of global warming, including (1) Climate Change Conference or UNFCCC; (2) the Copenhagen Agreement; (3) Kyoto Agreement and many more agreements, conferences or rules that have been made by various countries in this world. In addition to the issue of global warming, the increase in temperature (heating) of the city or more familiarly known as urban heat island is also the

\section{Revised Manuscript Received on December 30, 2019.}

* Correspondence Author

Mohammad Imran, STITEK Bina Taruna, Gorontalo, Indonesia. Email: imransains02ars@gmail.com

Sangkertadi, Samratulangi University, Manado, Indonesia Email: sangkertadi@yahoo.com

Cynthia E. V. Wuisang, Samratulangi University, Manado, Indonesia. Email: cyinthia.wuisang@unsrat.ac.id

Abdul Rahmat, Gorontalo State University, Gorontalo, Indonesia. Email: abdulrahmat@ung.ac.id

(C) The Authors. Published by Blue Eyes Intelligence Engineering and Sciences Publication (BEIESP). This is an open access article under the CC BY-NC-ND license (http://creativecommons.org/licenses/by-nc-nd/4.0/) same problem in the world of architecture (Sangkertadi, 2012).

\section{LITERATURE REVIEW}

Urban climate is the result of various interactions between natural and anthropogenic factors (air pollution; urban surface material; heat emissions), the city climate is controlled by many factors (Mulyandari, 2011). Uncontrolled urban activities are one of the factors causing an increase in the temperature of the urban average (Sangkertadi, 2013). The major contribution that has resulted in the accumulation of greenhouse gases in the atmosphere is human activity.

Cities with tall buildings that do not apply the concept of green architecture, pose a risk of rising environmental temperatures, this is due to the increasing number of heat absorbing and emitter elements and the production of heat from human activities such as motor vehicle (transportation) activities. The condition of the high temperature in the city center which is different from the air temperature on the outskirts of the city can be seen in the following illustration:

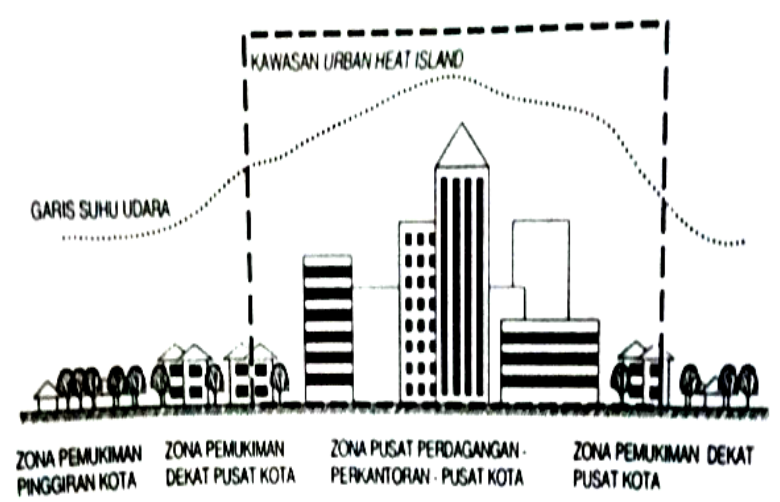

Figure 1. Urban Heat Island Pattern

Source : (Sangkertadi, 2012)

Measures for analyzing environmental or outdoor space, are generally based on empirical approaches from laboratory studies and direct data collection in the field (research objects). Outside space (public open space, pedestrian, park) which is also an area of socialization between various community groups, is the object of macro research. According to Frick (2007), natural materials (natural stone, wood, bamboo, and clay) do not contain substances that interfere with health, while artificial materials (plastic pipes, rock wool, chemical paint, adhesives) contain chemicals that are harmful to health. However, there are artificial materials that can be used as heat-absorbing materials that are safe for health, namely: (1) Recycling materials: waste, garbage, pulp, packaging materials, used cars, car tires, sawdust, pieces of glass. (2) Experiencing simple transformations: red stone, clay tiles, brick, conblock, metal, glass, and cement. Waste / waste is everything that is not used by individuals or groups (Mediastika, 2013).

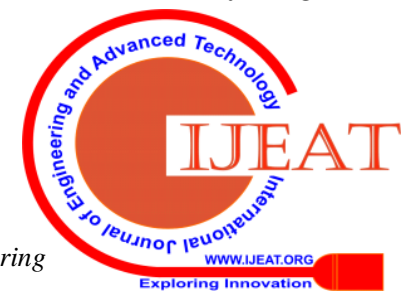


According to Sangkertadi (2013), an increase in the area of pavement and the use of metal materials or other reflective materials on solar radiation on the building envelope has accelerated the occurrence of symptoms of Urban Heat Island. In addition, transportation activities; urban industries and households also produce various types of exhaust gases which are the cause.

\section{METHOD OF RESEARCH}

The quantitative method is used in this study, considering that the quantitative method is used to analyze the quantity measurements of the variables studied or analyzed. The approach used in this study is a field survey in 4 (four) locations in the trade and service area of Manado City.

The research is conducted during 6 (six) months starting from May to October 2018 at 4 (four) locations : (1) FrontParking area of Bahu Mall; (2) Rear Parking area Bahu) Mall; (3) the area along Wolter Monginsidi street in front of Bahu Mall and (4) Parking area of Manado Town Square 3

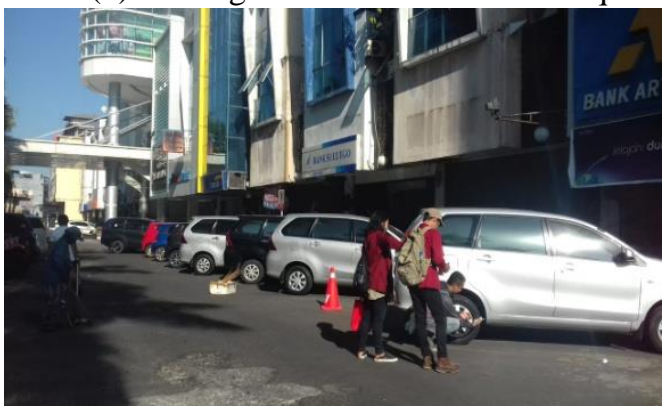

Figure 2. Front Parking Area of Bahu Mall, Manado Source : (Personal Documentation, 2018)

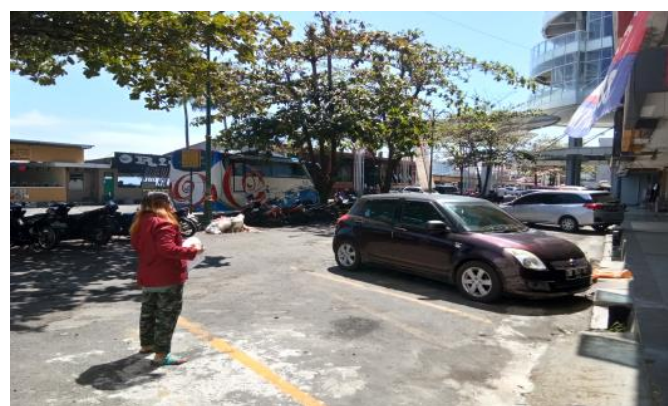

Figure 3. Rear ParkingArea ofBahu Mall, Manado Source : (Personal Documentation, 2018)

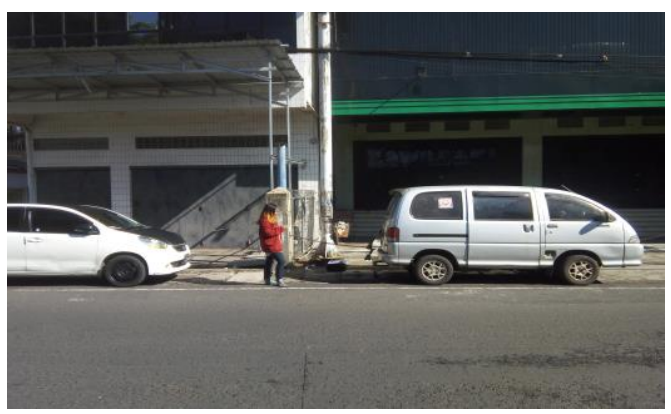

Figure 4. The Area along Wolter Monginsidi Street in Front of Bahu Mall

Source : (Personal Documentation, 2018)

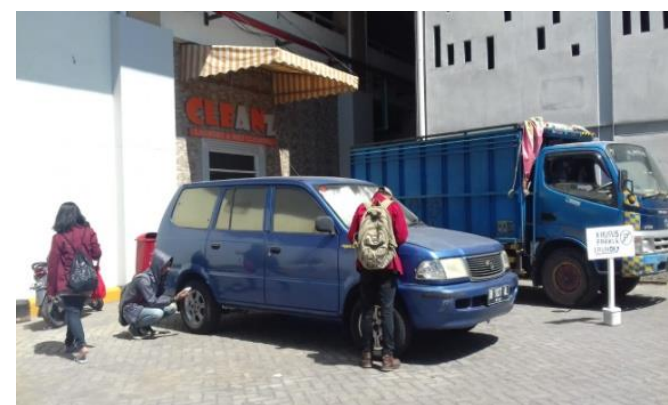

Figure 5. Parking Area of Manado Town Square 3 Source : (Personal Documentation, 2018)

\section{Data collection technique}

Primary data needed in this study are as follows:

Measuring the level of heat (temperature) in a location with a variable without a vehicle, with a vehicle parked (silent) without the engine running, with a vehicle parked (silent) with the engine running and with the vehicle running.

b) Calculating the number and activity of motor vehicles (cars and motorbikes) at the Bahu Mall parking area; parking area of Manado Town Square 3; the area along Wolter Monginsidi street in front of Bahu Mall and area along the Piere Tendean street in front of Manado Town Square.

2) Secondary data

a)Review of Literature

b) The Use of Map

c)Phase of Data Compilation and Interpretation

The research instrument regarding the increase in ambient heat (temperature) caused by motor vehicle activities in the city of Manado is detailed as follows:

1) Measurement Area

The measurement area of the Bahu Mall parking area is divided into 2 (two): (1) the front parking area of Bahu Mall (2) the rear parking area of Bahu Mall; The measurement area of Manado Town Square 3 parking area is divided into 2 (two): (1) The rear parking area of Manado Town Square and (2) The front parking area of Manado Town Square; The measurement area along the Wolter Monginsidi street in front of the Bahu Mall is divided into 2 (two) conditions: (1) the vehicle runs slowly (the volume of solid vehicles) and (2) the vehicle runs fast (the volume of the vehicle is tenuous); The measurement area along the Piere Tendean street in front of Manado Town Square is divided into 2 (two) conditions: (1) the vehicle runs slowly (the volume of solid vehicles) and (2) the vehicle runs fast (the volume of the vehicle is tenuous).

2) Documentation

The photoshoot was carried out on the elements of the location of the research area such as: parking conditions, function of area designation, vehicle traffic, the existence of fences; trees or material around the vehicle under study, road cover material (asphalt, paving block), type and color of the vehicle.Recording the results of measuring the temperature of the heat (temperature) environment is done to identify the heat of solar radiation obtained through the Outdoor Space Digital

Thermometer; Infra Red Thermometer; Thermo Couplemeter; Thermo Hygrometer and Anemometer.

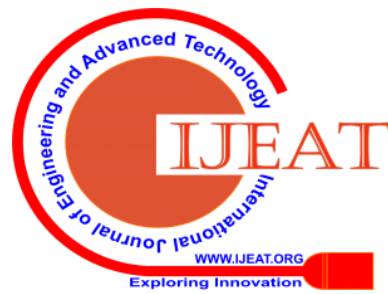


Data analysis uses quantitative analysis by collecting data in the field consisting of:

1) Solar heat radiation (ambient temperature / thermal) using tools :

a) Digital Thermometer (measuring ambient temperature);

b) Infra Red Thermometer (measuring material surface temperature);

c) Thermo Hygrometer (measuring air humidity);

d) Anemometer (measuring wind speed)

2) Collecting Data on Motor Vehicles (Cars) and Environmental Physical Data / Urban Areas:

a) Amount and activity of motor vehicles (cars)

b) The large of Area (research object)

c) and Regional Characteristics

The Measurement Results of Solar Heat Radiation Levels with Existing Formulas and "Sun" Application Assistance, Data processing using Mahoney Tables and Microsoft Excel.

Table 1. Average Temperature and Humidity in Manado City

\begin{tabular}{|c|c|c|}
\hline Month & $\begin{array}{c}\text { Temperature } \\
\left({ }^{0} \mathrm{C}\right)\end{array}$ & Humidity (\%) \\
\hline January & 28.4 & 89.5 \\
\hline February & 28.8 & 87.1 \\
\hline March & 28.5 & 90.2 \\
\hline April & 29.3 & 87.9 \\
\hline May & 29.6 & 85.3 \\
\hline Juny & 29.9 & 82.7 \\
\hline July & 30.3 & 75.6 \\
\hline August & 30.4 & 71.6 \\
\hline September & 29.6 & 83 \\
\hline
\end{tabular}

Source : (BMKG of Manado City, 2018)

\section{RESULT AND DISCUSSION}

The results of data processing represent several measuring samples that have a maximum average value of the ambient temperature of three (3) samples of data measured in each location can be seen as follows:

1) The Front Parking Area of Mall

The average temperature or temperature at the FrontParking Areais based on processed data from three (3) maximum measured samples, which is $36.1^{\circ} \mathrm{C}$.

2) The Rear Parking Area of Mall:

The average temperature or temperature at the Rear Parking Area is based on processed data from three (3) maximum measured samples, which is $34.8^{\circ} \mathrm{C}$.

3) Areas along Wolter Monginsidi Street in front of Bahu Mall:

The average amount of temperature or temperature along the Highwayin front of Bahu Mall Manado is based on processed data from three (3) maximum measured samples, namely $36.4{ }^{\circ} \mathrm{C}$.

4) Manado Town Square 3 Parking Area:

The average amount of temperature or temperature in the Front Parking Area of Manado Town Square 3 is based on the results of data processed from three (3) maximum measured samples of $39.4^{\circ} \mathrm{C}$.

Analysis of the data using the Mahoney table has been combined with the average temperature data that occurs in Manado during January to September 2018. The highest air temperature in Manado occurs in August, which can reach $31.9^{\circ} \mathrm{C}$, while the lowest temperature occurs at January is $26.6^{\circ} \mathrm{C}$

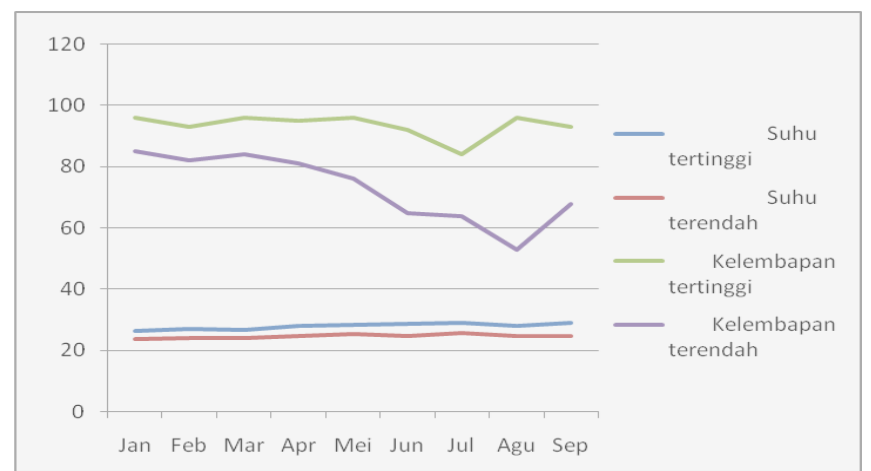

Figure 9. Chart of Highest and Lowest Temperature and Humidity in Manado City

Source : (BMKG of Manado City, 2018)

After analyzing the data between the results of data retrieval at the research location with the average temperature data issued by BMKG of Manado City in 2018 using the Mahoney table, then according to the above calculations are obtained:

Tabel 2. Research Outcomes

\begin{tabular}{|cc|}
\hline $\begin{array}{c}\text { Average Temperature } \\
\left({ }^{\mathbf{0}} \mathbf{C}\right)\end{array}$ & Research Location \\
\hline 34,8 & Rear Parking Area of Bahu Mall \\
36,1 & Front Parking Area of Bahu Mall \\
36,4 & Area Along Highway in front of Bahu \\
& Mall \\
39,4 & Front Parking Area of Manado town \\
& Square 3 \\
\hline
\end{tabular}

Source : (Analysis Data, 2018)

It can be seen from the table above, then there is a temperature increase of $\pm 5-10{ }^{\circ} \mathrm{C}$ if it is associated with the average temperature in the city of Manado. This is due to motorvehicle activities that occur at the Bahu Mall area, along the Wolter Monginsidi - Piere Tendean street and the Manado Town Square 3 area as the Manado trade service area.

\section{CONCLUSSION}

Global warming is a form of ecosystem imbalance on earth caused by an increase in temperature (thermal) environment. Global warming has become an issue and has become an international problem because it can endanger living things, the consequences of this global warming include increasing the temperature of the earth and the occurrence of climate change (climate change). Based on the results of research conducted in the front parking area of Bahu Mall; the rear parking area of Bahu Mall, along the Wolter Monginsidi - Piere Tendean street and the front parking area of Manado Town Square 3, obtained data that the average maximum ambient temperature is in the front parking area of Manado Town Square 3 which is $39.4{ }^{\circ} \mathrm{C}$. The number of motor vehicles that park both the condition of the engine is silent and the engine is on, various types of vehicle colors and vehicle types. In addition, there is no tree or shade in the parking area and the area directly adjacent to the Tendean Piere axis road, resulting in a high average ambient temperature. 


\section{ACKNOWLEDGMENT}

Thank you to :

1. DRPM, Ministry of Research, Technology and Higher Education for this research funding in 2018 -2019

2. Deputy Dean of the Engineering Faculty, Sam Ratulangi University Manado

3. Head of the Architecture Laboratory, Sam Ratulangi University Manado

4. Head of the STITEK Bina Taruna Gorontalo

5. Head of the Architecture Laboratory, STITEK Bina Taruna Gorontalo

\section{REFERENCES}

1. Evan, JM. (2007). The Comfort Triangles : A New Tool for Bioclimatic Design. PhD Thesis. Technische Universiteit Delf

2. Gealson, Karen and Rafael, Reif. (2007). Climate Classroom : What's up With Global Warming. National Wildlife Federation

3. Harsono, Tri Karyono. (2007). Pemanasan Bumi dan Tanggung Jawab Arsitek. Dipresentasikan dalam Seminar Pemanasan Bumi di Jurusan Teknik Arsitektur. Yogyakarta : Universitas Atmajaya. 6 September 2007

4. Idham, Nur Cholis. (2016). Arsitektur dan Kenyamanan Thermal. Yogyakarta : Andi

5. Mediastika, Christina E. (2013). Hemat Energi \& Lestari Lingkungan Melalui Bangunan. Yogyakarta : Andi

6. Mulyandari, Hesti. (2011). Pengantar Arsitektur Kota. Yogyakarta : Andi

7. Rencana Induk Riset Nasional 2015-2045. (2016). Tema dan Topik Riset Bidang Material Maju

8. Rusbiantoro, Dadang. (2008). Global Warming for Beginner Pengantar Komprehensif Tentang Pemanasan Global, O2. Yogyakarta

9. Sangkertadi. (2006). Fisika Bangunan Untuk Mahasiswa Teknik, Arsitektur dan praktisi. Bogor : Pustaka Wirausaha Muda

10. Sangkertadi. (2009). Petunjuk Pemakaian Program Matahari. Manado : Jurusan Arsitektur Fakultas Teknik Unsrat

11. Sangkertadi. (2012). Perhitungan Ventilasi dan Kenyamanan Termis pada Bangunan Tropis. Manado : Waja Utama

12. Sangkertadi. (2013). Kenyamanan Termis di Ruang Luar Beriklim Tropis Lembab. Bandung : Alfa Beta

13. Satwiko, Prasasto. (2008). Fisika Bangunan. Yogyakarta : Andi

14. Suarsana, Made dan Wahyuni, Putu Sri. (2011). Global Warming : Ancaman Nyata Sektor Pertanian dan Upaya Mengatasi Kadar CO2 Atmosfer. WIDYATECH Jurnal Sains dan Teknologi, Volume 11 Nomor 1 Agustus 2011. Hal. 31 - 46

15. Susanti, Indah dan Harjana, Teguh. (2006). Aspek Iklim dalam Perencanaan Tata Ruang. Jurnal Inovasi Online, Edisi Volume 8/XVIII/November 2006. ISSN : 0917-8376

16. Utina, Ramli. (2009). Pemanasan Global : Dampak dan Upaya Meminimalisasinya. Dipresentasikan dalam Seminar Pemanasan Bumi di Jurusan Biologi,Gorontalo : Universitas Negeri Gorontalo

\section{AUTHORS PROFILE}

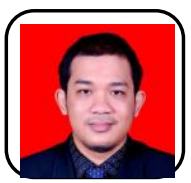

Mohammad Imran, STITEK Bina Taruna, Gorontalo, Indonesia. Email: imransains02ars@gmail.com

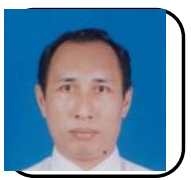

Sangkertadi, Samratulangi University, Manado, Indonesia Email: sangkertadi@yahoo.com

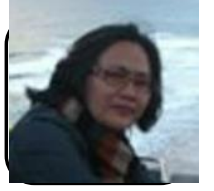

Cynthia E. V. Wuisang, Samratulangi University,

Manado, Indonesia. Email:

cyinthia.wuisang@unsrat.ac.id

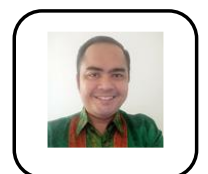

Abdul Rahmat, Gorontalo State University, Gorontalo, Indonesia. Email: abdulrahmat@ung.ac.id 